Contemporary Research in Education and English Language Teaching

ISSN: 2641-0230

Vol. 2, No. 1, pp. 16-35.

2020

Publisher: Learning Gate

DOI: 10.33094/26410230.2020.21.16.35

(C) 2020 by the authors; licensee Learning Gate

\title{
E-Learning in Bangladesh: A Study of Teachers' Behavioral Orientation and Affective Alignment in the Post-New Normal
}

\author{
A.S.M. Shamim Miah \\ University of Buraimi, Oman. \\ Email: miah.asmshamim@gmail.com \\ Md. Rasel Kabir \\ Green University of Bangladesh, Bangladesh \\ Email:raselkabir37@gmail.com \\ Sarmin Sultana \\ Alburaimi Private School, Oman \\ Email:sarminshamim@gmail.com
}

Received: 5 October 2020; Revised: 3 November 2020; Accepted: 23 November 2020; Published: 7 December 2020

\begin{abstract}
This study explores the teachers' behavioral and affective orientation to e-learning that is in practice at all the levels of education in Bangladesh i.e. primary school, secondary school, higher secondary school, college, and university. By investigating the reasons for such disarray, it proposes solutions to overcome them. It acquired its data through online surveys followed by quantitative analysis through descriptive inferential analogies of the logarithmically represented findings. The result of the study documents that teachers' preparation, technological know-how and adaptation to the e-learning platforms, their methods of teaching, measurement of outcomes, and mapping of curricula suggest that e-learning in Bangladesh is vitiated due to the diffusion in the teaching staff demographics and diluted apprehension of the e-learning. The paper's primary findings show that Bangladesh's progress from Education 1.0 to Education 3.0 is more affective and behavioral than cognitive in the implementation; wherein, the very concept of e-learning is diluted or spun around the idea of education via some usage of technology only, more specifically web conference applications which is indicative of Education 2.0 practices. There is no distinction made that separates online learning from e-learning, e-learning from distance and distance from blended learning, etc. in the current environment.
\end{abstract}

Keywords: E-learning, Blended learning, Online education, Pedagogy, Bangladesh, Orientation, Technology

\section{Introduction}

In todays' webified environment, where internet and technology play a vital role in transforming not only socio-cultural aspects of the human existence but also the paraphernalia along with it which includes education as well, does not aptly indicate readiness for andragogical or heutagogical migration as claimed by most of the academic institutions, especially in a Post-New Normal scenario that sprung from Covid-19 Pandemic. There is a certain form of e-learning practiced across all the institutions but the level, range, and degree of the practices lack absolutism to completely indicate alignment to Education 3.0 or above (i.e. andragogy or heutagogy) for which the entire world of education industry became far more conducive than Pre-Covid-19. The convergence from Education 1.0, that is to say, Essentialist, Individualist and Authoritarianist education (Gerstein, 2014) to Education 3.0 which is Heutagogical and Connectivist in approach to teaching and learning (Gerstein, 2014) has superficially taken place everywhere with phenomenal negligence to established curricula, teacher readiness, tech- 
support systems, syllabus, outcomes, graduate attributes, and quality. Just as mere usage of the World Wide Web, Internet, Social Media and evolving applications cannot be likened to the status of being in Education 3.0 or above.

Similarly, the adaption of the Web conferencing applications whether Google Meet, Microsoft Team, Zoom, GoToMeeting, Facebook Room or BigBlueButton etc., place the teachers slightly above Education 1.0 but not in Education 3.0 in comparison to its established indicators. Transformed curricula and methods of delivery alone do not signify adaptation to e-learning. There involve meticulous strategizing procedures, competencies, learning plans, means of delivery and assessment, methods of delivery and assessment, trained staffing, and mapped graduate attributes that adhere to either e-learning, online learning, distance learning, virtual learning or blended learning. Unfortunately, the practices show a rather deformed adaptation to any of the above learning types. This could be a result of the ill-informed strategizers who make the decisions for the most part. Discrepancies are also markedly noticeable in teaching staff demographics and their placements in the various levels of education. Thus, this article will delve deep into the various groups of teachers through a questionnaire to assess their behavioral and affective orientation to e-learning by evaluating their work experiences, best practices, means of lesson delivery, choice of teaching approaches, graduation production plans, and prospective teacher recruitment requirements against a set of established indicators in the context of Bangladesh. The data will be analyzed by means of quantitative inferential analogy.

\subsection{Background}

All the institutions in Bangladesh, that is to say, primary schools, secondary schools, higher secondary schools, colleges, universities and other institutions are claiming to have transformed from Education 1.0 to Education 3.0 through their work experiences, best practices, means of lesson delivery, choice of teaching approaches, graduation production attributes, and prospective teacher recruitment requirements against a set of established indicators; whereas, in reality their implementation of the elearning and teaching indicate the contrary. Their concept of e-learning is diluted and inseparable from its pseudonyms.

E-learning is different from distance learning, virtual learning, blended learning and such strands of the concept. However, they are certainly related. E-learning, Tamm (2019) asserts, "also referred to as online learning or electronic learning, is the acquisition of knowledge which takes place through electronic technologies and media. Tamm (2019) further implores that e-learning is "learning that is enabled electronically". In that view, typically, e-learning is one that is conducted on the Internet using the World Wide Web, where the students access their learning materials at their own choice of place and time. In that, e-Learning, Tamm (2019) points out "most often takes place in the form of online courses, online degrees, or online programs. More importantly, the 'e' in e-learning refers to 'how' and 'learning' in e-learning refers to 'what' and 'why'. E-learning is delivered via electronic devices like computers, tablets, laptops, or smartphones using words that are either in the form of spoken or printed text and pictures (which include illustrations, photos, animations, and videos). The 'what' in e-learning includes both content (that is, information) and instructional methods (that is, techniques) that make the learning of the content possible. Whereas, the 'why' in e-learning involves developing lessons intended to help learners reach their personal learning objectives or perform their jobs in ways that greatly facilitate and eventually improve their performance.

Distance learning is of a two-way mediated practice wherein communication plays an important role. Teaching precedes learning as it is non-contiguous and asynchronous in nature. The teaching involves guided didactic conversation following an industrialized education system utilizing dialogue structure and independence. This form of learning corresponds to multi or mass media education which is the result of Industrial Revolution (IR) 1.0 and IR 2.0 leading to the introduction of industrialized processes of teaching and learning. In the words of Merriam-Webster. (2020) distance learning is a "method of study where teachers and students do not meet in a classroom but use the Internet, e-mail, mail, etc., to have classes". Similarly, Lewison (2020) characterizes distance learning as one that needs 
"not include any in-person interaction with an instructor or study peers. Students study at home on their own, and the learning is more individual and varies on speed and timeline according to each individual student and their availability". Such learning involved the following:

- Tele / radio broadcasting systems.

- Conferencing based structure.

- Flexible learning.

- Online / multimedia / World Wide Web / interaction / asynchronous / constructivist learning.

- Intelligent flexible learning through automated business processes multimedia output from single source.

In the process, after the IR 3.0 things progressed to innovate interactive multimedia which:

- Is neither hardware nor software but teaching learning technology.

- Is interactive in nature (as learners are in control of the learning environment).

- Is multimedia (unlike TV \& computer-based), network.

- Combines text, pictures, animations, audio and video .

To conduct teaching and learning. That further led to multimedia (interactive multimedia) in order to:

- Stimulate learners.

- Engage learners.

- Push for more practices.

- Organize more resources.

By utilizing hyperlinks, involving 3D contents, and applying various learning styles to ensure more activities, more experiences and more learning through a control over learning and pace. This paved ways for online learning which is a method of learning that is no longer physically conducted in a physical infrastructure involving a classroom rather it is a "method for delivering instruction solely online, not as a variation in your teaching style." (Stauffer, 2020). It isn't too widely different from traditional classroom-based learning except in its choice of means and tools. Online learning is a learning system based on formalized teaching but with the help of electronic resources. Teaching, however, can be conducted inside or outside a traditional classroom, but with the involvement of computers and relevant accessories that enable teaching and learning everywhere and anytime. It is said that when you take courses online instead of in a physical classroom, it is online learning. In addition, Education 3.0 empowered the learners for:

- More problem solving.

- Active feedback.

- Understanding of abstract concepts.

- Simulation and role plays.

- User control and user interface and deep learning.

But, mobile learning is a variation of e-learning that Traxler (2005) explains as "any educational provision where the sole or dominant technologies are handheld or palmtop devices" that he believes include "phones, smartphones, personal digital assistants (PDAs) and their peripherals, perhaps tablet PCs and perhaps laptop PCs, but not desktops in carts and other similar solutions".

However, blended learning defines Allen and Seaman (2008) as "having between $30 \%$ and $80 \%$ of the course content delivered online" while they considered an online course as having "at least $80 \%$ of the course content delivered online". Similarly, an article states that, "at its heart virtual learning is about the learning that takes place outside of the school, or bringing what is outside of the school into the school. So, we are thinking about the online environment as a way of connecting students who may be located physically in a school with their learning that is somewhere else" Ten Trends 2013 (2013). 
Whereas, on-campus learning means a traditional classroom, where students attend classes in person and meet face-to-face with the professors and classmates, which is a setting that most people are used to (Walburg, 2020). It is the common set up from kindergarten onwards to the tertiary level where students attend class in-person, and the environment requires the least amount of adjustment in learning (Walburg, 2020).

Given all the above established concepts, the form of e-learning in Bangladesh, as may be already in implementation, is anything but atypical e-learning because the courses offered are still campusoriented, teacher-centered, and require face-to-face interaction, especially for assessment to occur let alone the Education 3.0 or above. That is neither online, virtual nor blended in implementation anywhere in Bangladesh. Moreover, e-learning as an advanced form for mass educating system emerged in Bangladesh in 1992, which is around two years after the Education 1.0 hit the world. As late as after 1998, the consideration to promote distance learning was underway (Islam \& Selim, 2006) when the entire world was about to enter Education 2.0. Given the situation Bangladesh was in, Bangladesh Open University (BOU) became the first and the only university to formalize the distance mode of education. The mode of education involved video and email which are Education 1.0 indicators. Considering the bulk of the online courses received at BOU, the means of lesson delivery included CDs (Islam \& Selim, 2006).

\subsection{Concept}

Oxford Languages and Google - English (2020) defines the term 'orientation' (or alignment) as "a person's basic attitudes, beliefs, or feelings in relation to a particular subject or issue" which in this research implies teachers' or education institutions' general perception about e-learning (or the related pseudonyms) in relation to the affective and behavioral domains of learning.

Alignment to Affective Domain Theory can be perceived as the emphasis given to e-learning practices by the Bangladeshi teachers and educational institutions in terms of associated feelings, tone, emotion, or a degree of acceptance or rejection. They have demonstrated affective objectives that vary from simple attention to selected phenomena to complex but internally consistent qualities of character and conscience (Krathwohl, Bloom, \& Masia, 1964). Such was the case because the teachers and institutions in Bangladesh have all been in receipt of the existing e-learning technology, material, or phenomena to committedly respond to them while valuing the implementation to assist in the formalization and characterization the same.

Similarly, the orientation to Behavioral Domain Theory in this research implies that "human behavior by analyzing the antecedents and consequences present in the individual's environment and the learned associations he or she has acquired through previous experience" have guided their choices as discussed in the findings (Angell, 2013). This alignment can further be perceived as "classical conditioning, operant conditioning, cognitively mediated behavioral theory, and functional contextualism" to already implemented e-learning in Bangladesh (Angell, 2013).

\section{Literature Review}

Education revolutions transpired through the communication revolution most often referred to Web 1.0, Web 2.0 or Web 3.0. The World Wide Web revolution began since the age of the Internet and like all the other major industries, education too picked momentum to redefine their place. Education or pedagogical transformations and Industrial Revolutions went parallel through the ages. Resultantly, the education industry underwent pervasive but rather active transformation through the phases of Industrial Revolutions (IR). For one thing, much before the first wave of IR, also known as IR 1.0, could even hit the world in 1784, Gutenberg press mechanically printed books that made education widespread as early as in the 1440s (History Com Editors, 2018). Following this, the IR 2.0 transpired in the 1870 s, which is markedly known as the age of mass production, when educational endeavors gained momentum across the nations while paving ways for the IR 3.0 in 1969 which revolutionized education entirely by allowing integration, migration, and adaptation to tech-supported education, 
social media and network-based education, and most importantly, some forms of online (electronic) or distance learning which later transformed into virtual learning. Consequently, IR 4.0 is on its way to unify all the physicality with that of what virtual there already is which is in turn a more social constructivist and collaborative approach for education. In a nutshell, the following table depicts the various phases of revolutions in Education and Web:

Table-1.

Educational Generations.

\begin{tabular}{|c|c|c|c|}
\hline & $\begin{array}{l}\text { Education } 1.0 \\
\text { (Web 1.0) }\end{array}$ & $\begin{array}{l}\text { Education } 2.0 \\
\text { (Web 2.0) }\end{array}$ & $\begin{array}{l}\text { Education } 3.0 \\
\text { (Web 3.0) }\end{array}$ \\
\hline $\begin{array}{l}\text { Teaching approaches } \\
\text { are ... }\end{array}$ & $\begin{array}{ll}\text { Dictated, } & \\
\text { authoritarianism, } & \\
\text { essentialism, } & \\
\text { individualism } & \text { to } \\
\text { prepare apprentice, or } \\
\text { acolyte }\end{array}$ & $\begin{array}{l}\text { Socially constructed to } \\
\text { rear up clients through } \\
\text { facilitation } \\
\text { assistance }\end{array}$ & $\begin{array}{l}\text { Socially constructed } \\
\text { and contextually } \\
\text { reinvented to promote } \\
\text { co-developers and co- } \\
\text { researchers }\end{array}$ \\
\hline Technology is & $\begin{array}{l}\text { Mostly unheard of, } \\
\text { confiscated at the } \\
\text { classroom door, or held } \\
\text { as digital refugees }\end{array}$ & $\begin{array}{l}\text { Cautiously adopted, } \\
\text { treated as digital } \\
\text { immigrants, teachers' } \\
\text { new knowledge }\end{array}$ & $\begin{array}{l}\text { Everywhere, immersive } \\
\text { and digital universe }\end{array}$ \\
\hline Schools are located & $\begin{array}{l}\text { In a building, locality, } \\
\text { premise, }\end{array}$ & $\begin{array}{l}\text { In a building or } \\
\text { somewhat online, over } \\
\text { the www, intranet, etc. }\end{array}$ & $\begin{array}{l}\text { Everywhere \& } \\
\text { thoroughly infused into } \\
\text { society }\end{array}$ \\
\hline Parents view schools & $\begin{array}{l}\text { Daycare, character } \\
\text { builders, }\end{array}$ & $\begin{array}{l}\text { Daycare, character } \\
\text { builders, and house of } \\
\text { knowledge }\end{array}$ & $\begin{array}{l}\text { A place for them to } \\
\text { learn, as well. }\end{array}$ \\
\hline Teachers are ... & $\begin{array}{l}\text { Degree qualified, } \\
\text { Licensed professionals }\end{array}$ & $\begin{array}{lr}\text { Certified professionals, } \\
\text { degree } & \text { qualified } \\
\text { practitioners, } & \end{array}$ & $\begin{array}{l}\text { Everyone, everywhere } \\
\text { with or without } \\
\text { licenses or degrees }\end{array}$ \\
\hline $\begin{array}{l}\text { Hardware \& } \text { software } \\
\text { in schools ... }\end{array}$ & $\begin{array}{l}\text { Are purchased at great } \\
\text { cost and ignored, are } \\
\text { immobile and fixed to a } \\
\text { particular location }\end{array}$ & $\begin{array}{l}\text { Are open source and } \\
\text { available at lower cost } \\
\text { but fixed to a location } \\
\text { with the flexibility of } \\
\text { world wide web access }\end{array}$ & 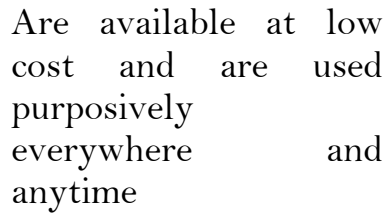 \\
\hline $\begin{array}{ll}\text { Industry } & \text { views } \\
\text { graduates as ... } & \end{array}$ & Assembly line workers & $\begin{array}{lr}\text { As } & \text { ill-prepared } \\
\text { assembly line workers } \\
\text { in a knowledge } \\
\text { economy }\end{array}$ & $\begin{array}{l}\text { as co-workers } \\
\text { entrepreneurs }\end{array}$ \\
\hline
\end{tabular}

Table 1 Educational Generations illustrates that Educational Generations progressed along with the digitization procedures; wherein, the generations can be perceived as Education 1.0, Education 2.0 and Education 3.0 as per the applied teaching approaches, technology, popular views, qualifications, and graduate attributes. The Education Generations are also widely known as Education 1.0, Education 2.0 and Education 3.0. 
Education 1.0 is marked by teaching approaches that adhere to dictatorship, authoritarianism, essentialism and individualism while focusing on preparing an apprentice, follower or assistant only. Learners have either never heard of any technology or suffered from confiscation of what little gadgets they possessed. Schools needed to be a localized premise for building character from licensed professionals. The graduates were viewed as mere assembly line workers.

However, Education 2.0 is identified as a period that emphasized on socially constructed facilitation of education wherein technology was cautiously adopted and users were treated as digital migrants. Though schools were still perceived as buildings, there was some form of online education via the World Wide Web, Intranet, etc. Teachers needed to be certified professionals or degree passed practitioners with ability to avail open sources to prepare knowledgeable assembly line workers.

On the other hand, Education 3.0 is perceived as social-constructivist in approach that allows learners to contextually reinvent avenues of knowledge and promote co-developers and co-researchers. In this generation, school is no longer viewed as a localized premise. It has become more of an immersive digital universe paving way for self-paced learning from anywhere and anytime. Also, the teacher's qualification has become an ornament rather than a requirement, and graduates are meant to become co-workers or entrepreneurs

\subsection{Research Questions}

Among the many twigging questions, this article centers round the main research question that is how can the Bangladeshi teachers with their work experience, their choices of the means of lesson delivery and their perceived future teacher recruitment requirements of Education 1.0 frame of mind aim for migrating their education system to Education 3.0 or above?

\section{Research Findings}

For one thing, the Bangladeshi teachers with work experience over 11 years form the major group of the teaching population across the nation who are actively teaching at the primary, secondary, higher secondary, college, and university level. They maintain a somewhat Education 1.0 mind frame, that is, authoritarianist, essentialist, and individualist in approach and prepare students who reflect or rather regurgitate a similar mind frame of their predecessors. This is quite evident in the results of the survey conducted to evaluate the teachers' orientation to e-learning by their work experiences (see Figure 1). Similarly, a good number of teachers with work experience between 0 to 5 years are indicative of Education 3.0 mind frame contrary to their best practices, choice of means of lesson delivery, methods of teaching or teaching approaches and most importantly to their plans for graduate attributes and future teacher recruitment requirements. They show a rather reverse migration from Education 3.0 to Education 1.0 in their plans to recruit future teachers which can be considered a plummeting trend away from andragogical and heutagogical supportive education environment of the Post-new Normal (see Figure 6) that is already in place in most of the first world nation.

Also, for the most part, the claims of the teachers that they are most suited and apparent adherents to Education 3.0 in their best practices fall short of proving the same in their choice of the means of lesson delivery employed during their teaching and learning. In that, they are extremely reversed and placed in Education 1.0. So, the question that arises is that how can teachers claiming to utilize all the best practices in their capacity to align with Education 3.0 choose the means of lesson delivery that belong to the Education 1.0? How can this receded approach to teaching place the teachers or their graduates in the Education 3.0 or above? Moreover, how can such an anomaly infested education system prepare graduates for the andragogical and heutagogical education environment that is being prepared for implementation in the Post-new Normal?

Moreover, teachers are ill-informed about the various transformation phases that education has entered since the IR 1.0. They merely believe that adaptation to technology, gadgets, internet, or applications are enough to place them in some form of e-learning. Contrary to the common belief, the education system of Bangladesh has only amalgamated into a rather mixed orientation to e-learning 
mostly due to the good number of the teachers who are in the decision-making body belonging to the Education 1.0 mind frame with over 20 years of work experience. They make it a point that face to face interaction is a prime requirement even for the university students who could as well adapt to the constructivist, socio-constructive or collaborative education system to become the graduates possessed with Education 3.0 or above attributes. Should such a transformation trend take effect, Bangladeshi universities will also meet the andragogical and heutagogical alignment criteria; thus, become fullfledged e-learning providers.

\section{Data Analysis}

\section{Orientation by work experience}

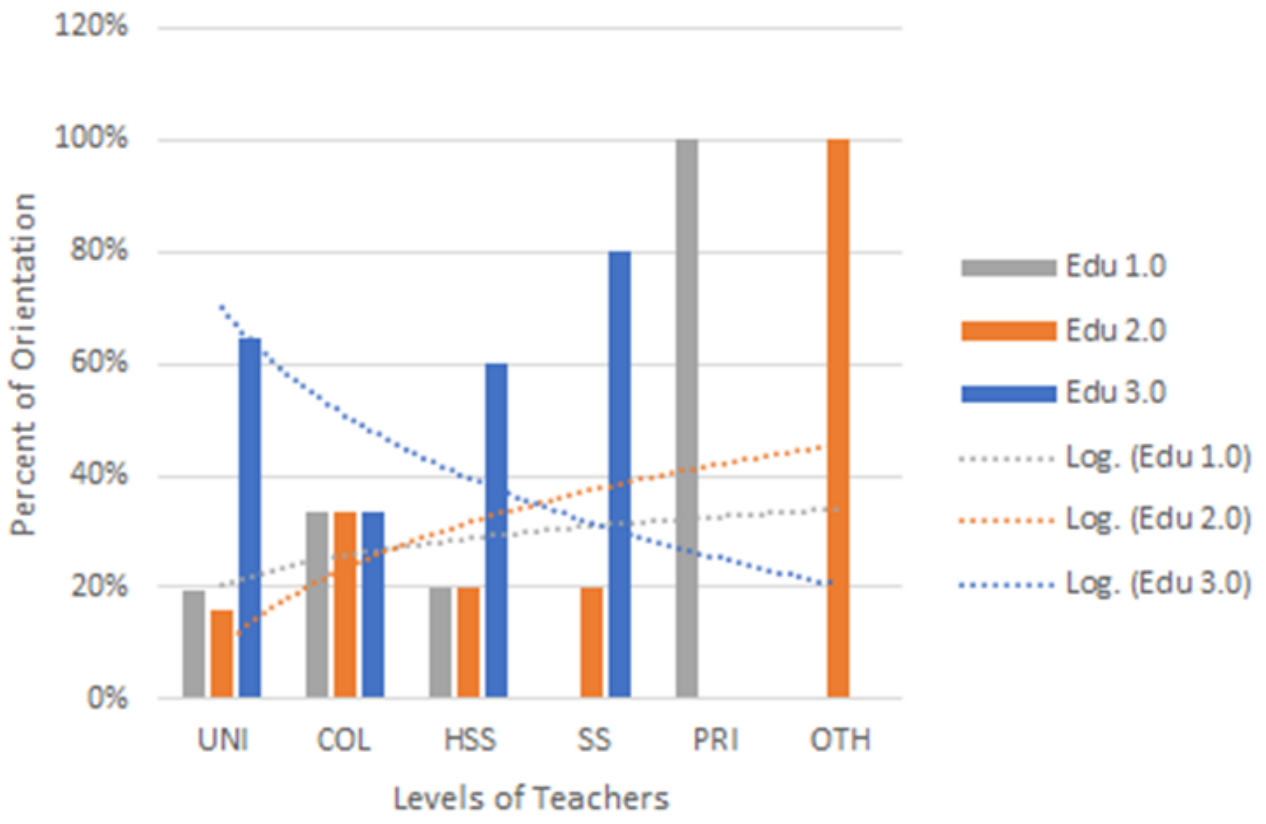

Figure-1.

Orientation of teachers by their work experience.

This bar graph depicts the affective and behavioral orientation of all the teachers to e-learning and teaching by their work experiences. Primary teachers (PRI) are oriented to Education 1.0 and teachers from other institutions (OTH) are oriented to Education 2.0. Whereas, the least number of university teachers are oriented to Education 1.0 compared to college and Higher Secondary School teachers. However, dramatically, no teachers from secondary school (SS) have indicated their orientation to Education 1.O. On the contrary, the highest number of teachers from secondary school have recorded their orientation to Education 3.0 compared to university (UNI), college (COL) and higher secondary school (HSS) teachers. Surprisingly, teachers from other institutions and primary level have negated their orientation to Education 3.0. On the whole, higher secondary school, college and university teachers are all somewhat well oriented to all the phases of Education revolutions i.e. Education 1.0, Education 2.0 and Education 3.0; thus, their best practices, means of delivery, teaching approaches, and graduate attributes can be expected to indicate readiness for Education 3.0 and above (see Figure 1). 


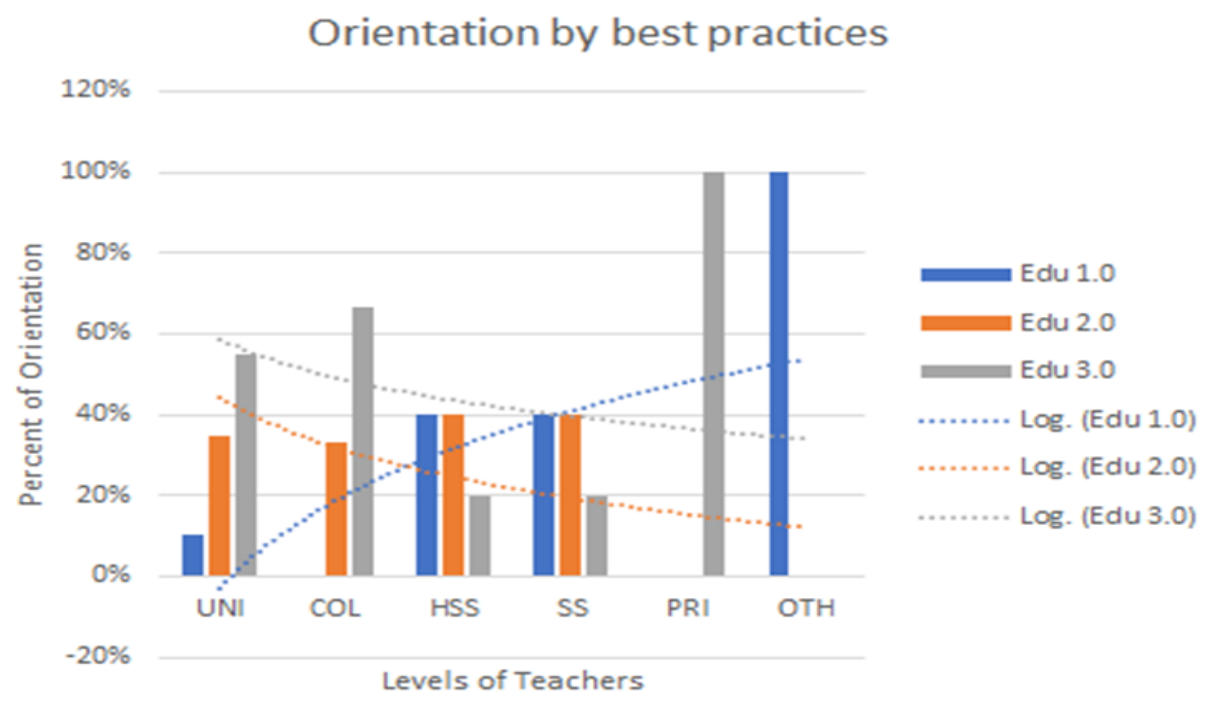

Figure-2.

Orientation of teachers by their best practices.

This bar graph illustrates the affective and behavioral orientation of all the teachers by their best practices from primary school (PRI), secondary school (SS), higher secondary school (HSS), college (COL), university (UNI) and other institutions (OTH) to e-learning and teaching in Bangladesh. The highest orientation to Education 3.0 is noticed among the primary school teachers compared to their counterparts; whereas, the highest orientation to Education 1.0 is indicated by the teachers from other institutions. However, the best practices of Education 3.0 are dramatically on the rise from secondary school to college and dips a little among the university teachers. The rate at which Education 1.0 and Education 2.0 best practices applied at the higher secondary school and secondary school stands equal at $40 \%$ compared to college and university teachers who indicated a slight dip in their Education 1.0 aligned best practices. Overall, the distribution of the best practices is well aligned, except in the university where they should have nullified their Education 1.0 practices to migrate to Education 3.0 and above which is the need of the current Education environment (see Figure 2).

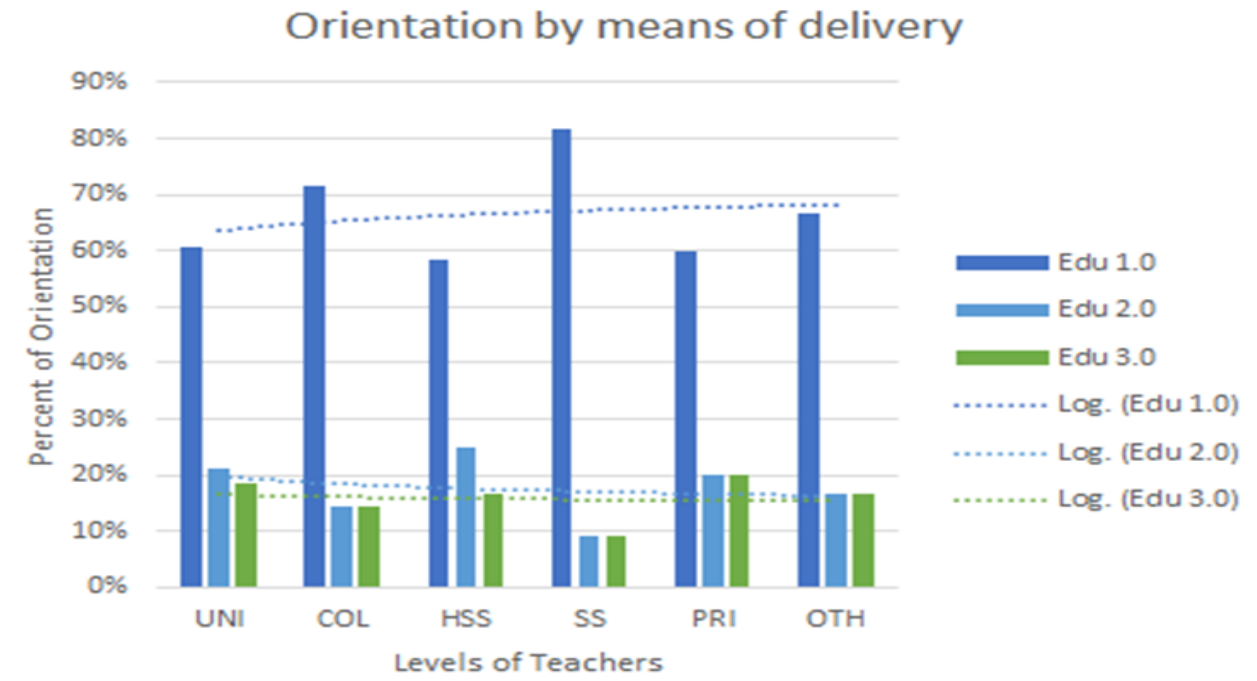

Figure-3.

Orientation of the teachers by their choice of means of lesson delivery.

Contemporary Research in Education and English Language Teaching
ISSN: $2641-0230$
Vol. 2, No. 1, pp. $16-35,2020$
DOI: $10.33094 / 26410230.2020 .21 .16 .35$
C) 2020 by the authors; licensee Learning Gate


This bar graph demonstrates the affective and behavioral orientation of all the teachers by their choice of means of lesson delivery from primary school (PRI), secondary school (SS), higher secondary school (HSS), college (COL), university (UNI) and other institutions (OTH) to e-learning and teaching in Bangladesh. Surprisingly, the highest number of the primary teachers chose such means of lesson delivery that indicate their orientation to Education 3.0 compared to secondary school, higher secondary, college, university, and even the teachers from other institutions. Similarly, higher secondary school teachers show the highest orientation by their choice of means of lesson delivery for Education 2.0. Whereas, contradictorily, all the teachers indicate extreme orientation to Education 1.0 through their choice of means of lesson delivery with highest in the secondary school, and the lowest in the higher secondary school. Overall, this graph indicates absolute negation to all the claims recorded in the teachers' affective and behavioral orientation by their work experiences and best practices. In order for the migration to Education 3.0 and above to happen, the orientation of the teachers should have indicated dramatic rise level wise in the usage of means of lesson delivery that move from Education 1.0 to Education 2.0 and so on (see Figure 3).

\section{Orientation by teaching approaches}

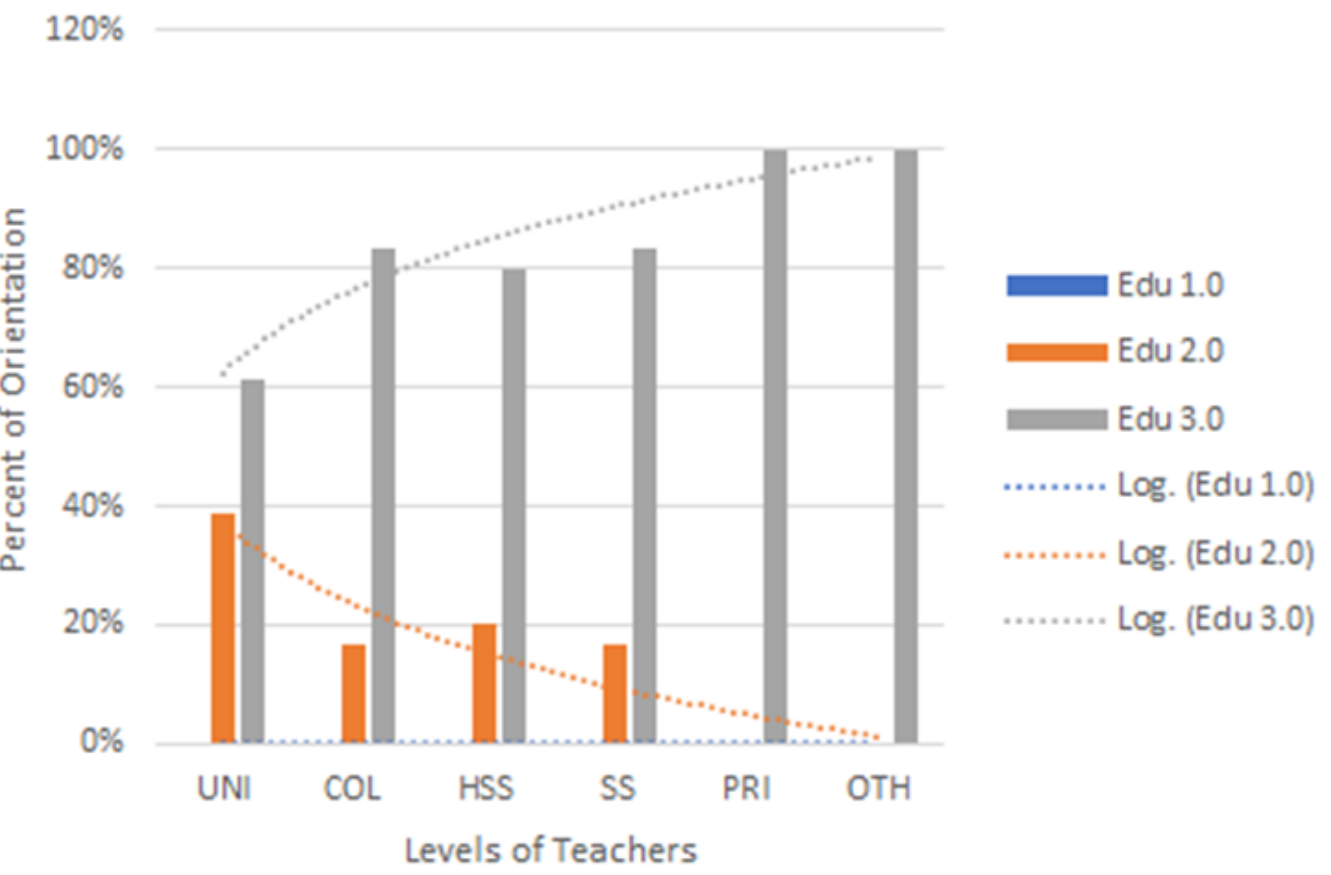

Figure-4.

Orientation of teachers by the methods of teaching or teaching approaches.

This bar graph shows the affective and behavioral orientation of all the teachers by their methods of teaching or teaching approaches from primary school (PRI), secondary school (SS), higher secondary school (HSS), college (COL), university (UNI) and other institutions (OTH) to e-learning and teaching in Bangladesh. Dramatically, the highest number of teachers from primary and other institutions claim their orientation to Education 3.0 through their teaching approaches; whereas, the least number of teachers from university indicate their orientation to Education 3.0. All through from primary school, secondary school, higher secondary school, college, university and other institutions the graph indicates a dipping trend except among the college teachers. Surprising, no teachers from primary and other institutions show their orientation to Education 2.0. Even more surprisingly, no teachers from any level indicate their orientation to Education 1.0 in their methods of teaching or teaching approaches. Overall, 
this graph illustrates a contradiction to all the teachers' claims of the best practices, and means of lesson delivery (see Figure 4).

\section{Orientation by Graduate Path Plan}

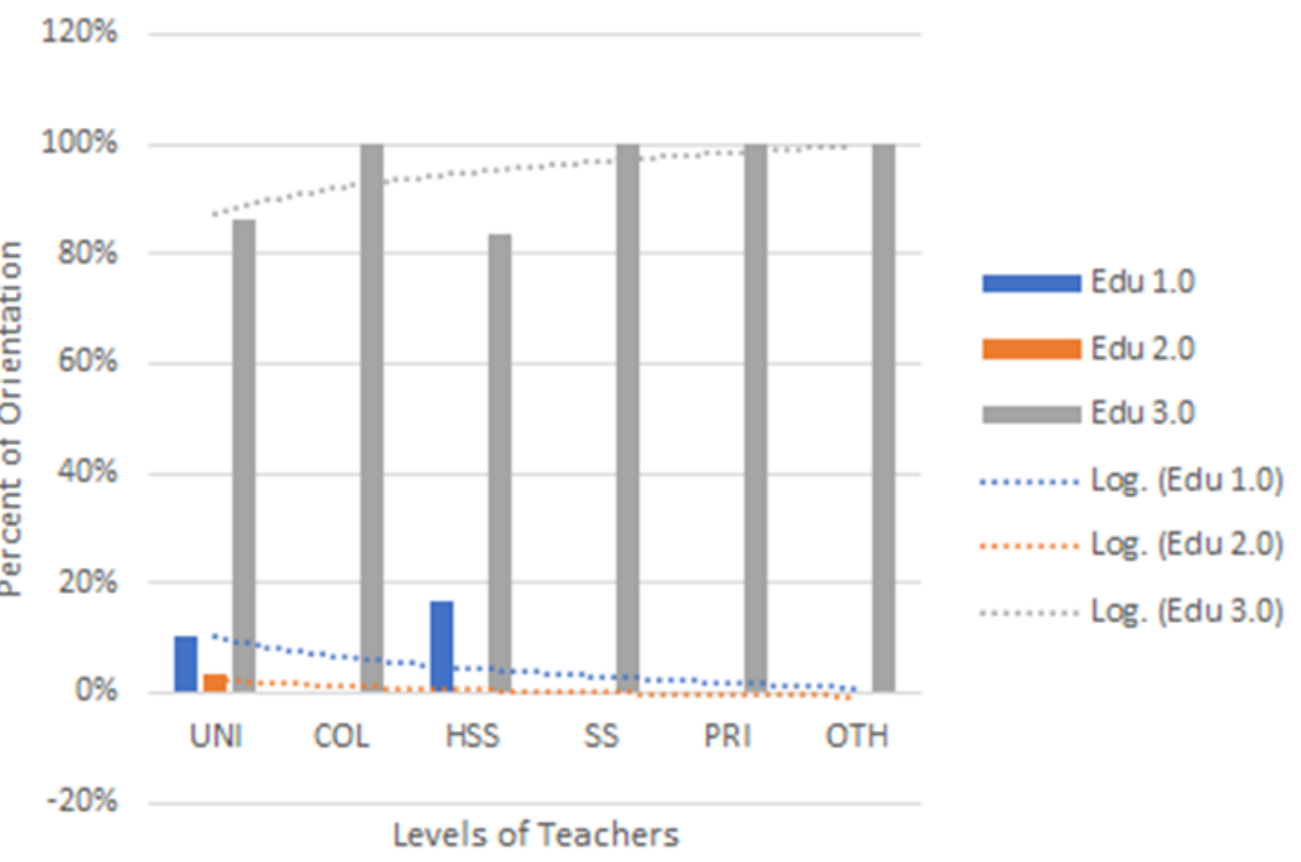

Figure-5.

Orientation of teachers by their graduate producing plans.

This bar graph illustrates the affective and behavioral orientation of all the teachers by their plans for producing graduates from primary school (PRI), secondary school (SS), higher secondary school (HSS), college (COL), university (UNI) and other institutions (OTH) to e-learning and teaching in Bangladesh. Except with a slight fluctuation among the higher secondary, and university, all the teachers from other institutions, primary, secondary school, and college indicate that they are producing graduates with Education 3.0 attributes. Whereas, only university teachers indicated their graduates are getting ready for Education 2.0. However, the trend of the Education 1.0 attributes drops from higher secondary to university graduates. But no teachers from other institutions, primary, secondary, higher secondary and college indicated any trend of producing graduates with Education 1.0 attributes. Overall, this graph demonstrates an anomaly in the graduate attribute orientation because primary, secondary, higher secondary and college teachers are meeting their students face - to - face daily at least 5 days a week to deliver their lessons, interact, and assess which align them to Education 1.o. Also, their adaptation to the usage of wiki, website, and web conferencing apps place them in Education 2.0. Hence, this distribution is indicative of an absolute negation to their claims of orientation to e-learning by work experience, best practices, means of lesson delivery and teaching approaches (see Figure 5). 


\section{Orientation by Teachers' Credential \\ Requirements}

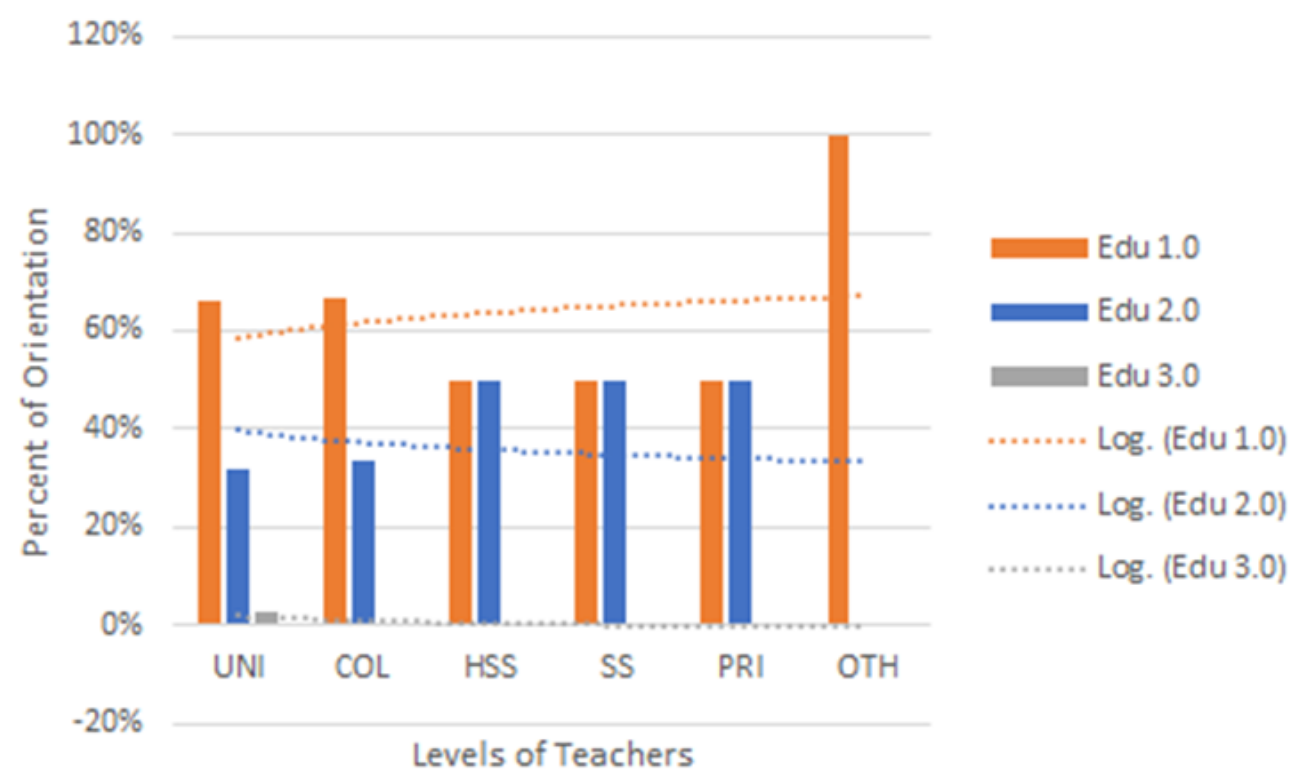

Figure-6.

Orientation of teachers by their future teacher recruitment requirements.

This bar graph indicates the affective and behavioral orientation of all the teachers by their future teacher recruitment requirements from primary school (PRI), secondary school (SS), higher secondary school (HSS), college (COL), university (UNI) and other institutions (OTH) to e-learning and teaching in Bangladesh. The highest number of teachers indicating that they would require Education 1.0 attributes in the credentials of the future recruits belong to the other institutions. Similarly, the trend is on the dramatic rise among the primary to university teachers. Contrarily, the primary, secondary and higher secondary school indicate highest orientation to Education 2.0 in their demand for teachers' credentials compared to college and university teachers who show a slight dip. However, except for below 2 percent university teachers, no teacher from other institutions, primary, secondary, higher secondary, and college indicated that they would demand for Education 3.0 credentials from their future teacher recruits. Overall, this graph negates the trends of orientation of the teachers e-learning by work experience, the best practices, the means of lesson delivery, the teaching approaches and the graduate attributes plans. The question that becomes vital to ask is how can the migration from Education 1.0 to Education 3.0 and above be materialized with recruits indicating their orientation to Education 1.0 and Education 2.0 only? (see Figure 6).

\subsection{Synthesis}

The data analyses show a clear mismatch of the teachers' affective and behavioral orientation to elearning. Their best practices, means of lesson delivery, and future teacher recruitment requirement indicate that they are oriented to Education 1.0 (see Appendices 1,2 \& 3), but their teaching approaches and graduate outcome attributes show their alignment to Education 3.0 (see Appendices 4 \& 5). Whereas, their work experience indicates alignment to Education 2.0 (see Appendix 6). Hence, the research question stands as to how can Bangladeshi education system migrate to Education 3.0 and above with such a discrepancy in their staffing of the teachers, their experiences, best practices, means of lesson delivery, teaching approaches, graduate outcome attributes and teacher qualification 
requirements? The findings further assert that orientation of the teachers are led from affective and behavioral domains rather than cognitive (see Figure 7).

\section{The Synthesis}

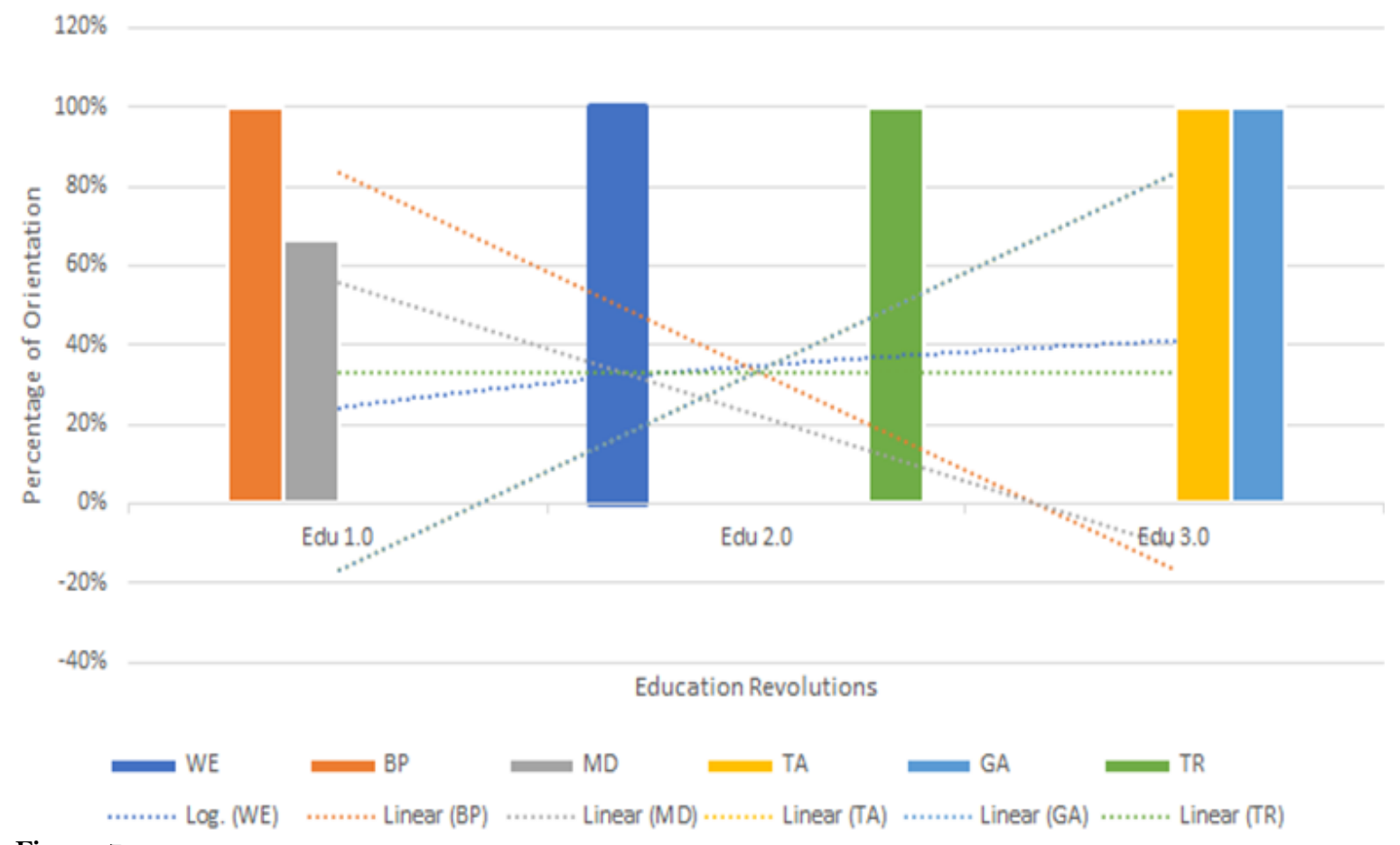

Figure-7.

The Synthesis of the teachers to E-Learning in Bangladesh

\section{Recommendations}

In view of the findings and syntheses, this article recommends that Bangladeshi education system, especially in the aftermath of the COVID-19 breakout, and their Post-new Normal transcendence, should prelude a more Education 1.0 conducive environment at the earlier levels of education that gradually leads to Education 2.0 in the mid-levels of education, and finally attains Education 3.0 or above at the higher levels of education which may be university. This is perceptibly attainable if the teachers and educational institutions:

- institutions step out of the dictatorialist, authoritarianist, and essentialist approaches that is apprentice and acolyte focused.

- encourage socially constructed educational environment that reduces the teachers' role from the dictatorialist, authoritarianist, and essentialist to that of facilitators and assistants.

- welcome the usage of technology without being too cautious and restrained to new knowledge and promote the digital migration through revisiting syllabus, outcome mapping, and teaching styles that is not premise restrictive.

- develop hybrid (also known as Blended learning) environment; thus, allowing to immerse into the e-learning which is both premises accommodated and online in nature.

- recognize the graduate outcome attributes of all those who had some form of e-learning during their graduation studies.

- do not make it impervious for graduates with licenses, certificates, and diploma qualified teachers. 
- avail the World Wide Web, internet, and subsidized or low-cost applications or devices to promote e-learning.

\section{References}

Allen, E., \& Seaman, J. (2008). Staying the course: Online educaiton in the United States, 2008. Needham: Babson Survey Research Group.

Angell, B. (2013). Behavioral theory: Subject: Addictions and substance Uuse, aging and older adults, health care and illness, mental and behavioral health. Encyclopedia of Social Work. Paper presented at the National Association and Social Workers Press and Oxford University Press.

Gerstein, J. (2014). Moving from education 1.0 Through education 2.0 towards education 3.0. Retrieved from: https://scholarworks.boisestate.edu/edtech_facpubs/104/. [Accessed October 07, 2020].

History Com Editors. (2018). Printing press. History. Retrieved from: https://www.history.com/topics/inventions/printingpress.

Islam, M., \& Selim, A. M. (2006). Current status and prospects for e-learning in the promotion of distance education in Bangladesh. 114 Turkish Online Journal of Distance Education, 7(1), 114-119.

Krathwohl, D. R., Bloom, B. S., \& Masia, B. B. (1964). Taxonomy of educational objectives. The Classification of educational goals, handbook II: Affective Domain. Retrieved from: https://serc.carleton.edu/resources/20681.html. [Accessed October 07, 2020].

Lewison, K. (2020). What is distance learning: The benefits of studying remotely. University of the People. Retrieved from: https://www.uopeople.edu/blog/what-is-distance-learning

Merriam-Webster. (2020). Merriam-Webster.com dictionary. Retrieved from: https://www.merriamwebster.com/dictionary/distance\%20learning.

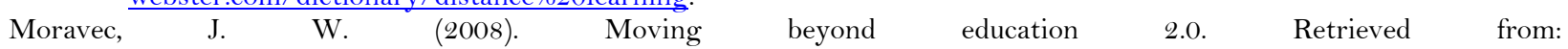
https://www2.educationfutures.com/blog/2008/02/moving-beyond-education-20/. [Accessed October 07, 2020].

Oxford Languages and Google - English. (2020). Retrieved from: https://languages.oup.com/google-dictionary-en/. [Accessed October 07, 2020].

Stauffer, B. (2020). What's the difference between online learning and distance learning? Retrieved from: https://www.aeseducation.com/blog/online-learning-vs-distance-learning. [Accessed October 07, 2020].

Tamm, S. (2019). What is E-learning? Retrieved from: https://e-student.org/what-is-e-learning/. [Accessed October 07, 2020].

Ten Trends 2013. (2013). Retrieved from: https://core-ed.org/research-and-innovation/ten-trends/2013/virtual-learning/. [Accessed October 07, 2020].

Traxler, J. (2005). Defining mobile learning. Paper presented at the IADIS International Conference Mobile Learning 2005. Qwara, Malta: International Association for Development of the Information Society.

Walburg, E. (2020). How to decide between an online and on-campus education. Cornerstone University. Retrieved from: https://www.cornerstone.edu/blog-post/how-to-decide-between-an-online-and-on-campus-education.

\section{Appendices}

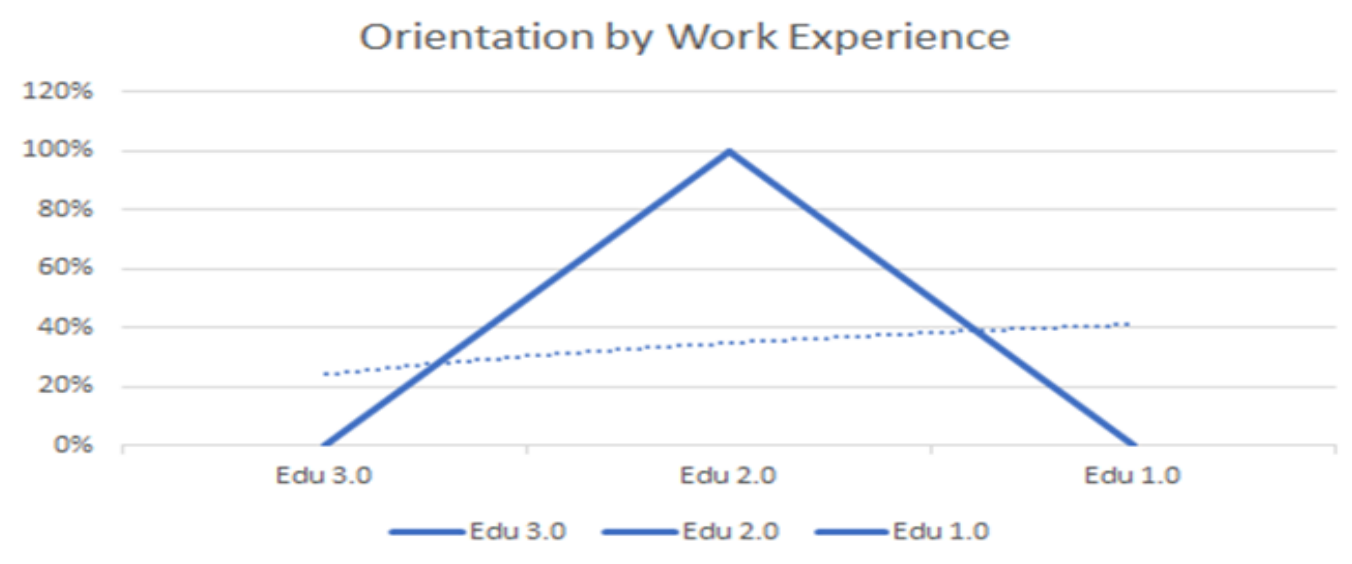

Appendix-1.

Teachers' work experience.

Contemporary Research in Education and English Language Teaching

ISSN: 2641-0230

Vol. 2, No. 1, pp. 16-35, 2020

DOI: $10.33094 / 26410230.2020 .21 .16 .35$

(C) 2020 by the authors; licensee Learning Gate 


\section{Orientation by their best practices}

$120 \%$
$100 \%$
$80 \%$
$60 \%$
$40 \%$
$20 \%$
$0 \%$
$-20 \%$
$-40 \%$

Appendix-2.

The best practices.

\section{Orientation by means of delivery}

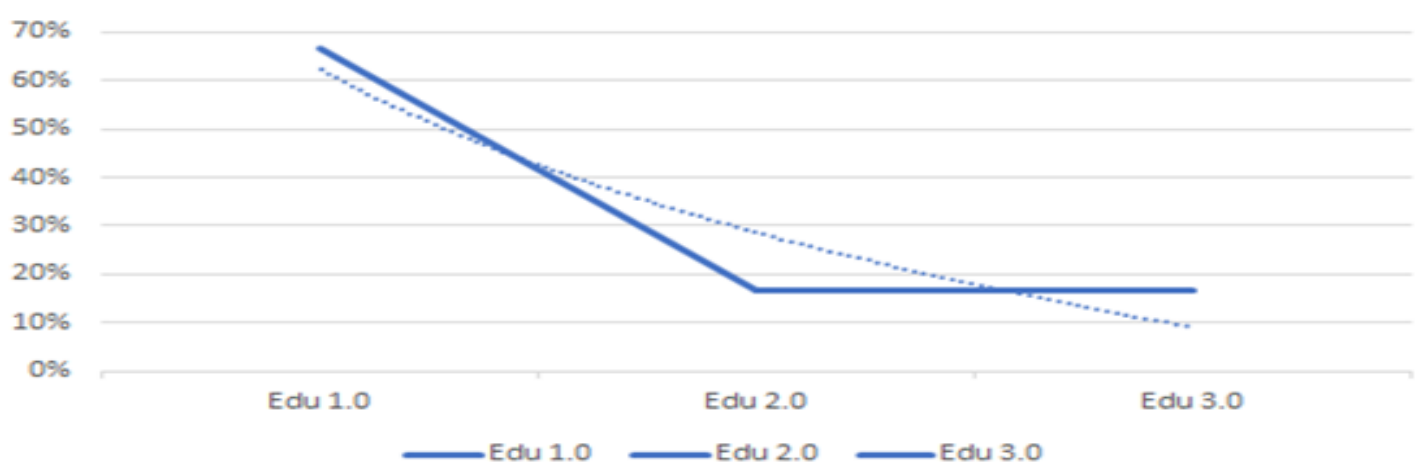

Appendix-3.

The means of lesson delivery.

\section{Orientation by Teaching Approaches}

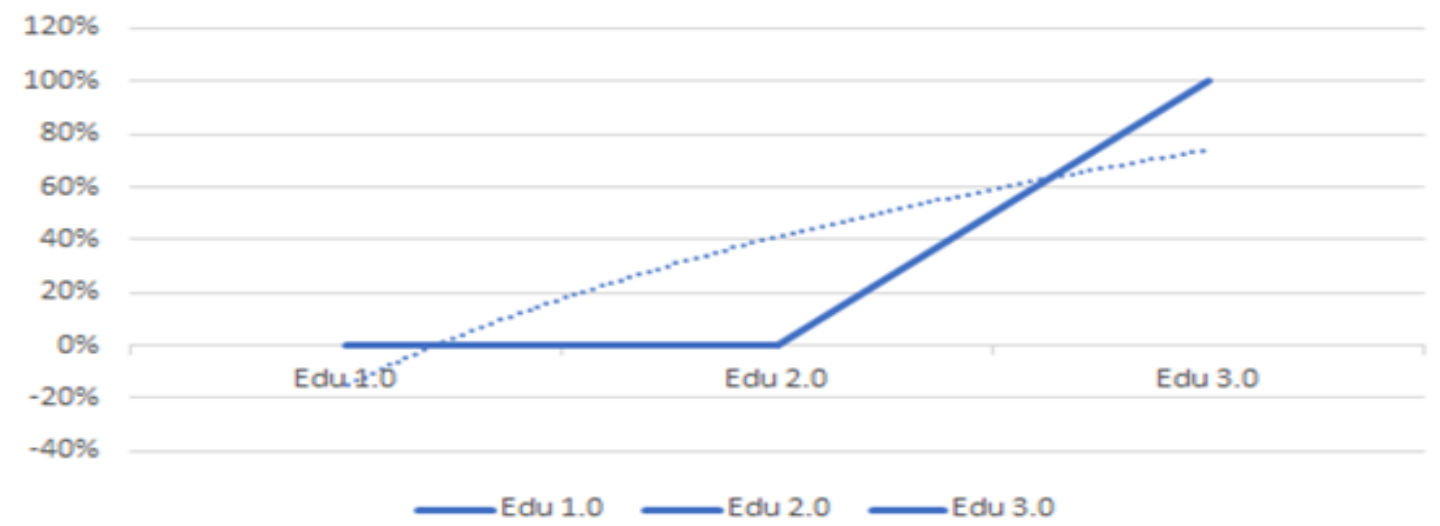

Appendix-4.

The teaching approaches.

Contemporary Research in Education and English Language Teaching
ISSN: $2641-0230$
Vol. 2, No. 1, pp. $16-35,2020$
DOI: $10.33094 / 26410230.2020 .21 .16 .35$
C) 2020 by the authors; licensee Learning Gate




\section{Orientation by Graduate Path Plans}

$120 \%$

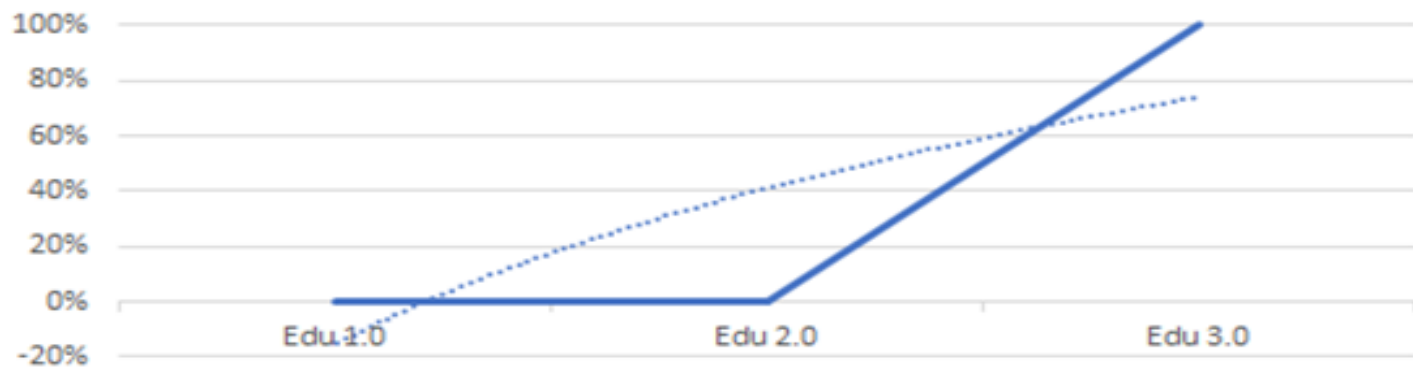

$-40 \%$

Edu $1.0-E d u 2.0-E d u 3.0$

Appendix-5.

The graduate attributes.

\section{Orientation by Teachers' Credential Requirements}

$120 \%$

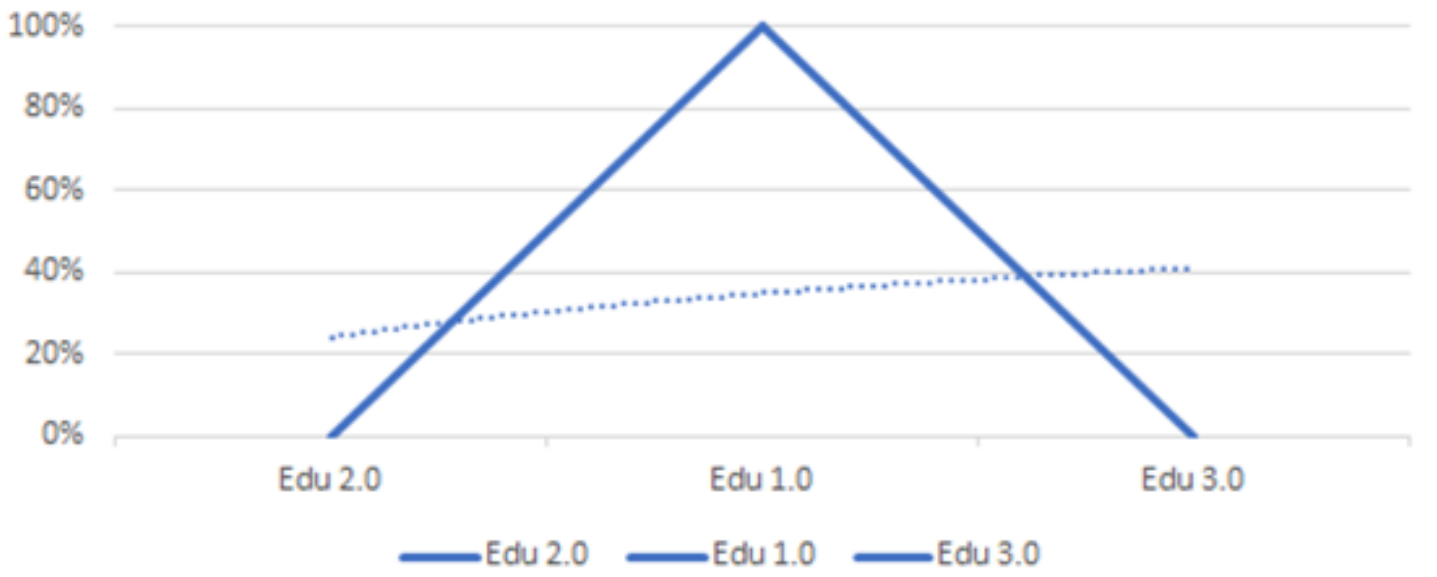

Appendix-6.

The future teacher recruitment requirements.

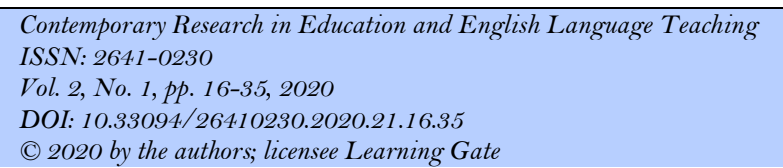




\section{Appendix-7.}

The survey questionnaire

$10 / 3 / 2020$

Survey Questionnaire

\section{Survey Questionnaire}

Dear respondent,

This survey questionnaire aims to evaluate your personal orientation and place in the current industrial revolution from the perspective of educational paradigm shift. Your responses will remain classified with the team that is carrying out this survey. No part of this survey will reveal your name, demographics or identity unless previously mutually agreed with you in advance.

All your responses will be tallied against a set of criteria to identify your place and orientation in the current paradigm shift. Should you require a sample of your responses or results, please feel free to request for it. You may write to Mr. A.S.M. Shamim Miah, Chairman, ELearning Committee, University of Buraimi by sending an email at shamim.a@uob.edu.om or write to Rasel Kabir, Assistant Professor, Green University of Bangladesh at raselkabir37@gmail.com.

Thank you for your participation and responses.

* Required

1. Email address *

Basic

Information

Please read the questions. Then, answer by selecting the alternative that matches your credentials.

2. Where do you work? *

Mark only one oval.

Pre-primary School

Primary School

Secondary School

Higher Secondary School

College

University

Other

Contemporary Research in Education and English Language Teaching

ISSN: 2641-0230

Vol. 2, No. 1, pp. 16-35, 2020

DOI: $10.33094 / 26410230.2020 .21 .16 .35$

(C) 2020 by the authors; licensee Learning Gate 
$10 / 3 / 2020$ Survey Questionnaire

3. What subject do you teach? *

4. Specify the range that matches your work experiences in years. *

Check all that apply.

$\square 0$ to 5 years
$\square 6$ to 10 years
$\square 11$ to 15 years
$\square 20$ years and above

Questions related to your orientation

This set of questions are aimed at identifying your teaching orientation.

5. What from the following do you consider the best practice? *

Mark only one oval.

Teacher should be the sole validating entity and deliverer of knowledge when teaching in a classroom.

Teacher should allow social validation following an establish methods of delivery of knowledge in a classroom.

Teacher should welcome social validation to reinvent delivery of knowledge in a classroom.

Other:

Contemporary Research in Education and English Language Teaching
ISSN: 2641 -O230
Vol. 2, No. 1, pp. $16-35,2020$
DOI: $10.33094 / 26410230.2020 .21 .16 .35$
C) 2020 by the authors; licensee Learning Gate


6. What among the following are the best means of delivering a lesson to students? Choose as many as you like. *

Check all that apply.

CD, DVD

Flash Drive, Pen Drive, Portable Drive, USB

TV Channel Subscription, YouTube Subscription, Video Streaming Channel Subscription Website, Wiki, SCROM, Open Sources, FREE online sites, etc.

Web Application, Mobile Application, LMS, VLE, Web conferencing Apps. etc. White Board, Classroom, Face-to-Face (physically)

Other:

7. What among the following do you consider as the best approach to teaching? *

Check all that apply.

$\square$ Teacher to student (one way) with teacher being the transmitter of knowledge contents.

$\square$ Teacher to student and student to student with teacher being the validating factor of knowledge contents.

$\square$ Teacher to student and student to teacher where both interact to validate knowledge contents.

Other:

8. How in your opinion should we view the graduates? *

Check all that apply.

$\square$ as future assembly line workers

$\square$ as ill-prepared future assembly line workers in knowledge economy

$\square$ as future co-workers and entrepreneurs

Other:

Vol. 2, No. 1, pp. 16-35, 2020

DOI: $10.33094 / 26410230.2020 .21 .16 .35$

(C) 2020 by the authors; licensee Learning Gate 
9. What among the following should a teacher's credentials include? *

Check all that apply.

$\square$ license to teach as a professional in the field

$\square$ academic accomplishments. For example: B.A. / B.Sc., M.A./ M.Sc. / Mphil / Phd. etc.

Diploma or anything in the field (Degree not required)

Other:

So kind of you of you to have completed the survey questionnaire. We will reiterate the pledge as above that no part of this survey shall be revealed anywhere in any form. Should you require a sample of your response or result, feel free to request. Looking forward to working with you again.

Thank Regards,

you!

A.S.M. Shamim Miah

Chairman, E-Learning Committee,

University of Buraimi

This content is neither created nor endorsed by Google.

\section{Google Forms}

https://docs.google.com/forms/d/1VnilJ6PRpb1Y1j7Bwc3gFC4N9ZXkT1AGB402bilMuW8/edit

Source: https://forms.gle/b8pSXMqV9LVo6u4w8

Contemporary Research in Education and English Language Teaching

ISSN: 264.1-0230

Vol. 2, No. 1, pp. 16-35, 2020

DOI: $10.33094 / 26410230.2020 .21 .16 .35$

(C) 2020 by the authors; licensee Learning Gate 


\begin{tabular}{|c|c|c|c|c|}
\hline \multicolumn{5}{|l|}{ Appendix-8. } \\
\hline Timestamp Email Adotress $s$ & Where do you work? & \multicolumn{2}{|c|}{ peat the } & 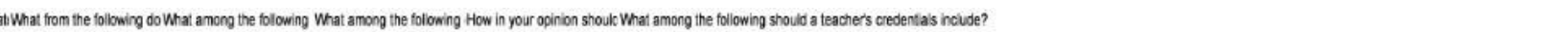 \\
\hline 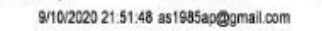 & o Universty & Engish & 61010 years & 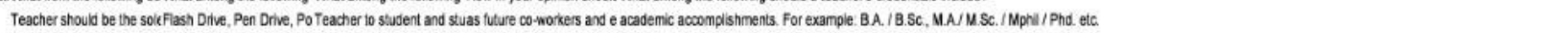 \\
\hline 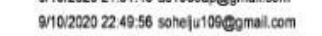 & O Hehter Seconday School & English & Oos Syears & 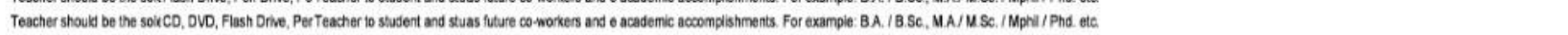 \\
\hline 910/202023.44:00 mmeziciunivedu & o Universty & Engish hanguage & 20 years and above & 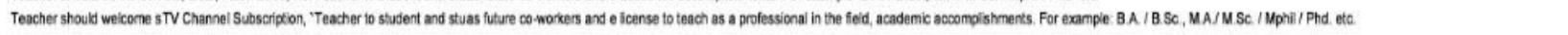 \\
\hline 9/112020 10.3250 e ensethulalmagnanal com & 0 Seconday School & English & 6 to 10 years & 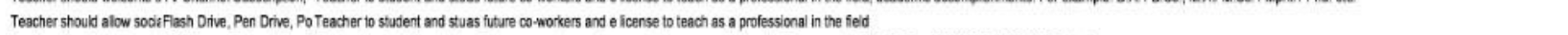 \\
\hline 91112020 14:42:12 sabbinossain1781@gmal & o other & Engish & 61010 years & 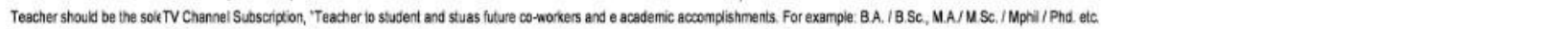 \\
\hline 9/112020 17:17:20 nyadhossan557egmallcc & o oher & English & 6010 years & 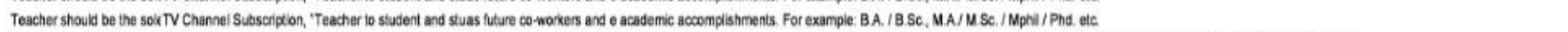 \\
\hline 9/11/2020 175121 bartholamew markgagnail. & o University & Engish language and raer. & or 20 yeas and above & 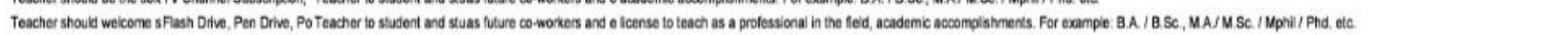 \\
\hline 9/11202021.56:44 Sarminshamingamaic con & O Higher Seconcdary School & I Engish language ard Rert & arta 6 is 10 years & 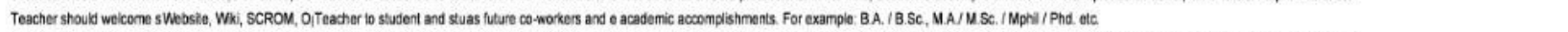 \\
\hline 9/112020 23:18.43 mash03111975egrmalicot & OPrimary School & English & 111015 years & 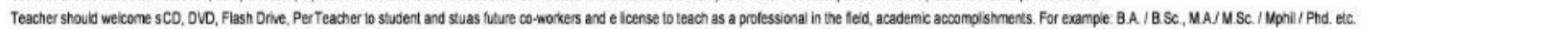 \\
\hline 9/12202020 237.31 smunbggnalicon & o Secondary School & English & Owo 8 years & 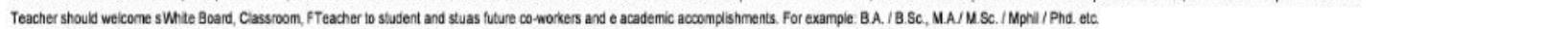 \\
\hline 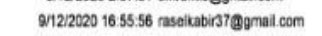 & O Unversty & English & 6010 years & 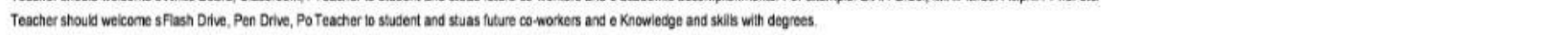 \\
\hline 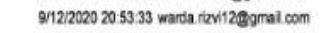 & o University & English languag \& L terat: & atu11 io 15 years & 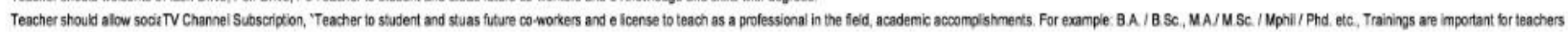 \\
\hline 9/1222020 21:51:47 mikulbiswash Gigmalicon & o College & English & 20 years and above & 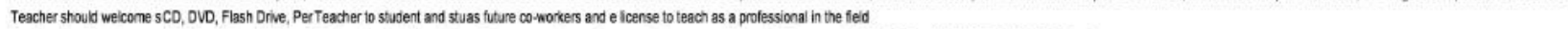 \\
\hline 9/12/2020 22:39:09 habibrahman juggamail $\infty$ & o Universty & Engish & 0105 years & 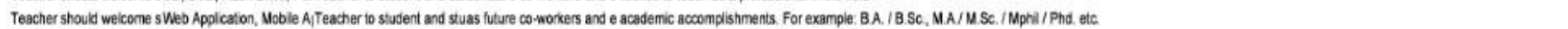 \\
\hline 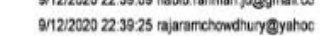 & O Hehter Seconday School & | Engish & 20 years and above & 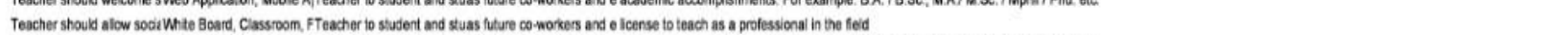 \\
\hline 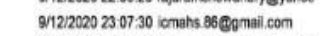 & o Collepe & Engish languase & 6 to 10 years & 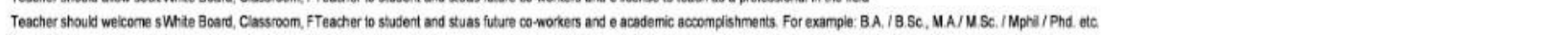 \\
\hline 9/1322020 11:49:47 shaharazchanamggnait. & o University & Engish & 11 to 15 years & 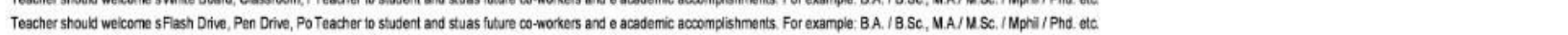 \\
\hline 9/13/2020 17.42.48 roffqu/141274 Ggmail.com & o College & Engish & 11 to 15 years & 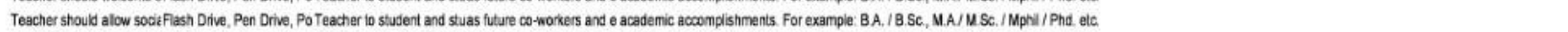 \\
\hline 9/4:2020 1720.02 mj|ahangiralam_amongy: & o Secondary School & English & 0 ob 8 years & 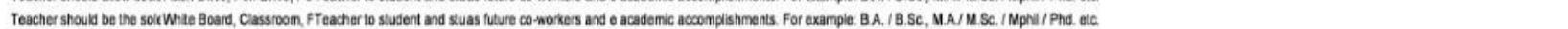 \\
\hline 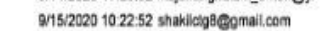 & o University & Engish Language and Lite & ine 0 o 5 years & 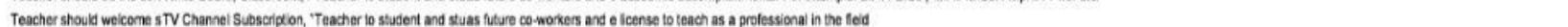 \\
\hline 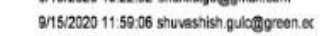 & o University & English & 0105 years & 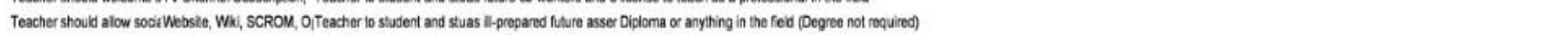 \\
\hline 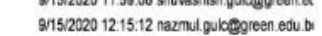 & o Universty & English & 0105 years & 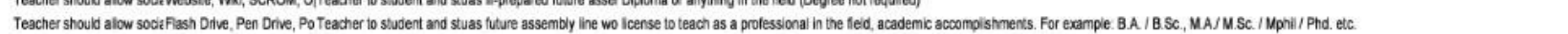 \\
\hline 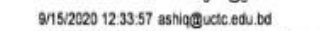 & O University & Acoouning 8 Finance & 0105 years & 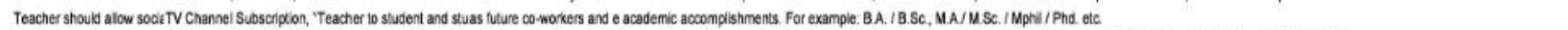 \\
\hline 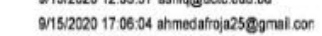 & o Universty & Psychology & 0 oto 5 years & 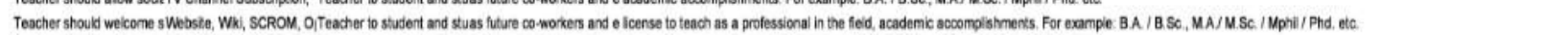 \\
\hline 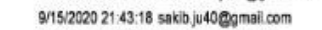 & o Collepe & English & 0 to 5 years & 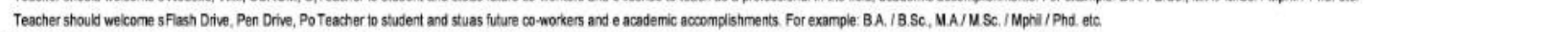 \\
\hline 9/15220202 23040423 saljoghoshogunc.ca & o Universty & Lingustics & 0 to 5 years, 6 to 10 year. & 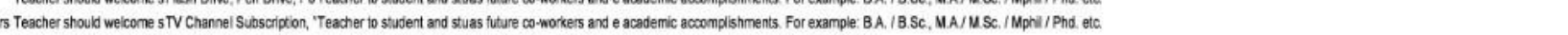 \\
\hline 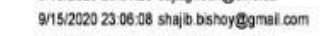 & O Higher Seconcary School & II Engish & Oos syears & 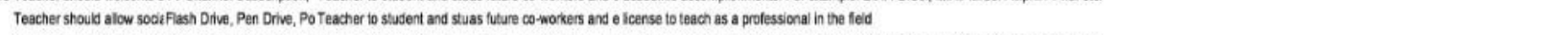 \\
\hline 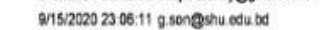 & o Universiy & Ergish Larguageg and Lite & He 0105 years & 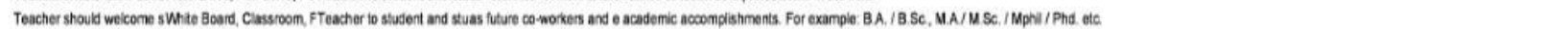 \\
\hline 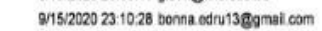 & a University & English & 0105 years & 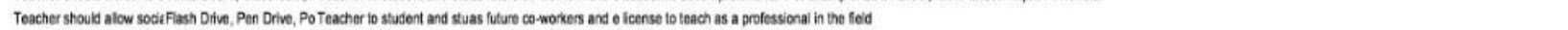 \\
\hline 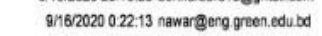 & O Universtiy & Engish & 0 os 5 years & 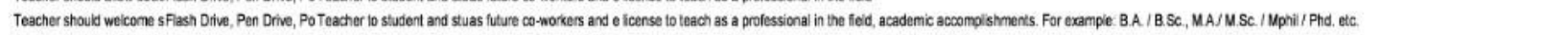 \\
\hline 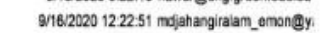 & O Secondary School & Englsh & Oto 5 years & 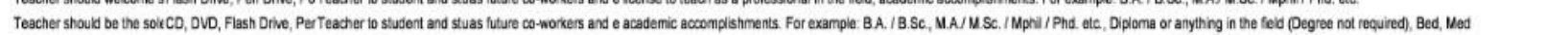 \\
\hline 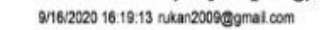 & o Universty & Engish language & 20 years and above & 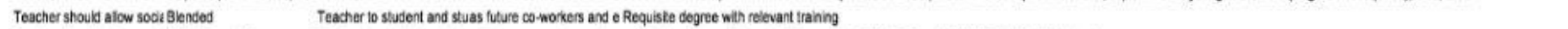 \\
\hline 916622020 17.46.45 heialivesegmalicom & 0 Secondary Schoal & English & 0 to 5 years & 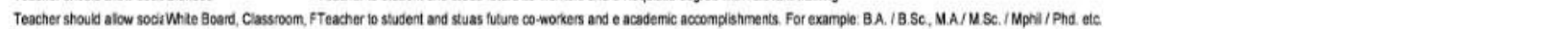 \\
\hline 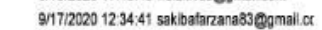 & o Universty & Sociology & 0105 years & 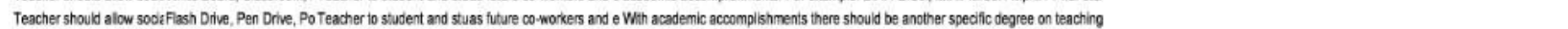 \\
\hline 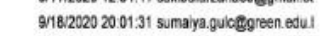 & o University & Engish Hiteraure and lang & g.010 5 years & 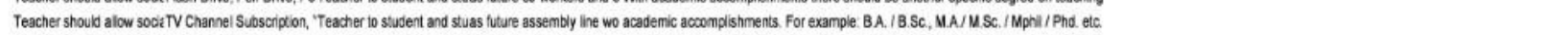 \\
\hline 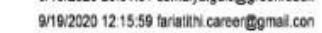 & o University & English & 0105 years & 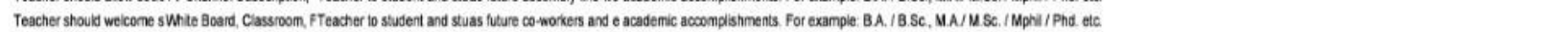 \\
\hline 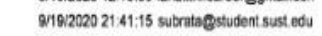 & O Unversty & cherristy & 0 to 5 yours & 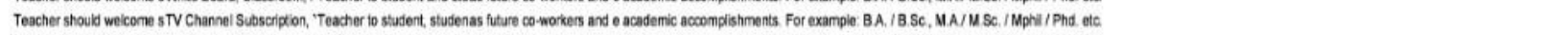 \\
\hline 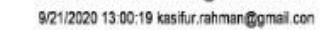 & 0 University & English & 6 to 10 years & 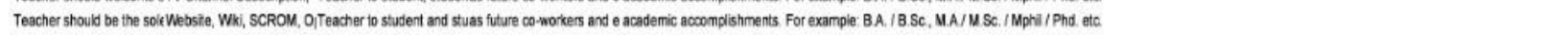 \\
\hline 92/122020 1327:45 atyejegmaic com & o College & History & 61010 years & 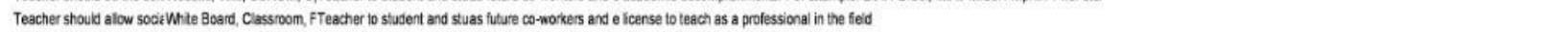 \\
\hline 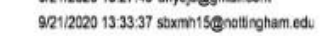 & o College & Social Work & Oos Syears & 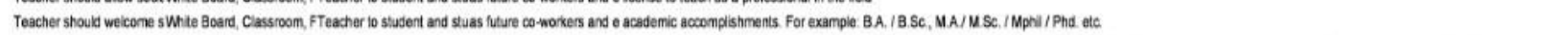 \\
\hline 9/21/2020 $16 \cdot 3922$ munirzaman02227 Ggmai & o University & Socology & 005 years & 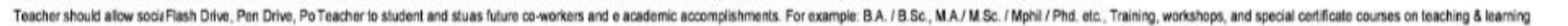 \\
\hline 921120201928.10 mulatwaid erggijstedut & o University & English Literatume & 005 years & 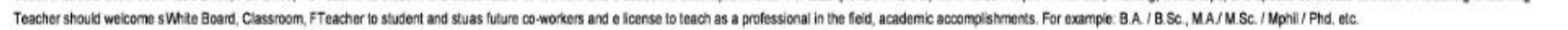 \\
\hline 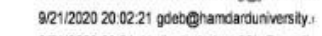 & o University & Engish & 0105 years & \\
\hline 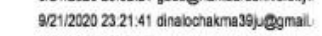 & o University & English & & 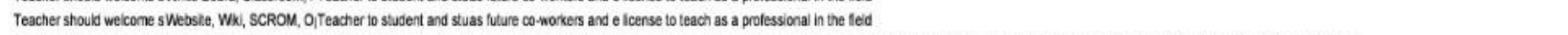 \\
\hline 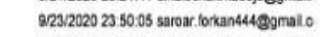 & 0 Higher Seconcary School & I Cheristy & ONo S years & 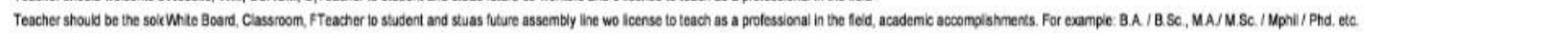 \\
\hline 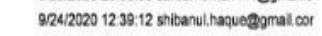 & 0 Universis & Mechanica Engineering & 0 os 5 years & 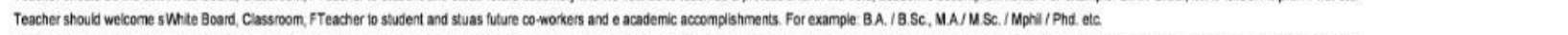 \\
\hline 9:24:2020 16.25.27 alamin141008gomail.com & o University & Mechanical engineering & 0 to 5 years & 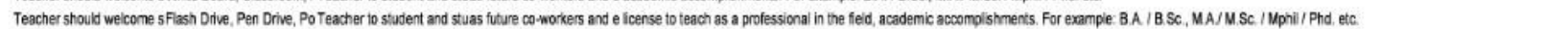 \\
\hline
\end{tabular}

